\title{
Differential Resource Allocation in Deer Mice Exposed to Sin Nombre Virus
}

Eric Wilson

ewilson4@byu.edu

Erin M. Lehmer

Christine A. Clay

Stephen St. Jeor

Denise M. Dearing

Follow this and additional works at: https://scholarsarchive.byu.edu/facpub

Part of the Microbiology Commons

Original Publication Citation

Physiological and Biochemical Zoology 8.5(27): 514-521.

\section{BYU ScholarsArchive Citation}

Wilson, Eric; Lehmer, Erin M.; Clay, Christine A.; St. Jeor, Stephen; and Dearing, Denise M., "Differential Resource Allocation in Deer Mice Exposed to Sin Nombre Virus" (2007). Faculty Publications. 235. https://scholarsarchive.byu.edu/facpub/235 accepted for inclusion in Faculty Publications by an authorized administrator of BYU ScholarsArchive. For more information, please contact ellen_amatangelo@byu.edu. 


\section{Differential Resource Allocation in Deer Mice Exposed to Sin Nombre Virus}

\author{
Erin M. Lehmer ${ }^{1, *}$ \\ Christine A. Clay ${ }^{2}$ \\ Eric Wilson ${ }^{3}$ \\ Stephen St. Jeor ${ }^{4}$ \\ M. Denise Dearing ${ }^{5}$ \\ ${ }^{1}$ Department of Biology, Fort Lewis College, Durango, \\ Colorado; ${ }^{2}$ Department of Biology, Westminster College, Salt \\ Lake City, Utah; ${ }^{3}$ Department of Microbiology and \\ Molecular Biology, Brigham Young University, Provo, Utah; \\ ${ }^{4}$ Department of Microbiology, University of Nevada School \\ of Medicine, Reno, Nevada; ${ }^{5}$ Department of Biology, \\ University of Utah, Salt Lake City, Utah
}

Accepted 3/22/2007; Electronically Published 7/13/2007

\section{ABSTRACT}

The resource allocation hypothesis predicts that reproductive activity suppresses immunocompetence; however, this has never been tested in an endemic disease system with free-ranging mammals. We tested the resource allocation hypothesis in wild deer mice (Peromyscus maniculatus) with natural exposure to Sin Nombre Virus (SNV). Immunocompetence was estimated from the extent of swelling elicited after deer mice were injected with phytohemagglutinin (PHA); swelling is positively correlated with immunocompetence. After livetrapping deer mice, we determined their reproductive state and SNV infection status. Males were more likely to be seropositive for SNV than females (37\% vs. 25\%) and exhibited $10 \%$ less swelling after PHA injection. The swelling response of females differed with both infection status and reproductive condition. There was also a significant infection status by reproductive condition interaction: nonreproductive, seropositive females experienced the least amount of swelling, whereas females in all other categories experienced significantly greater swelling. The swelling response of males differed with both SNV infection status and reproductive condition, but there was no significant infection status by reproductive condition interaction. Seronegative males elicited greater swelling than seropositive males regardless

*Corresponding author; e-mail: lehmer_e@fortlewis.edu.

Physiological and Biochemical Zoology 80(5):514-521. 2007. (C) 2007 by The University of Chicago. All rights reserved. 1522-2152/2007/8005-6127\$15.00 DOI: $10.1086 / 520128$ of reproductive status. In contrast to the resource allocation hypothesis, these results do not indicate that reproductive activity suppresses immunocompetence of deer mice but rather suggest that chronic SNV infection reduces immunocompetence. Sex-based differences in swelling indicate that SNV modulates the immune system of female deer mice differently than it does that of males, particularly during reproduction. We propose that differences in resource allocation between males and females could result from inherent sex-based differences in parental investment.

\section{Introduction}

The resource allocation hypothesis proposes that expenditures associated with maintenance functions (e.g., growth, locomotion, and immune system function) are dynamic and at times may be compromised to satisfy more immediate functions (Sheldon and Verhulst 1996; Sinclair and Lochmiller 2000; Nelson et al. 2002). Thus, during periods when the energetic demands of reproduction are primary, other maintenance functions, including immunocompetence, will be compromised, and animals may become more susceptible to disease (FestaBianchet 1989; Gustafsson et al. 1994). For example, laboratory studies have demonstrated that several species of small passerine birds expend roughly the same amount of energy when subjected to an immune challenge as during egg production (Martin et al. 2003). Similar patterns have been reported in mammals. For example, captive white-footed mice (Peromyscus leucopus) have been shown to shift their allocation of resources away from reproductive functions when mounting an immune response; their testis mass was significantly reduced after subcutaneous injection with an immune challenge agent (Derting and Compton 2003). Although the hypothesis that reproducing mammals have compromised immunocompetence is pervasive, this idea has not been empirically tested in natural populations of mammals exposed to native disease agents. We evaluated this hypothesis in wild populations of deer mice (Peromyscus maniculatus) exposed to Sin Nombre virus (SNV).

Deer mice are the primary reservoir and vector for SNV. Secondary reservoirs include other Peromyscus species (Otteson et al. 1996) and Neotoma lepida (Dearing et al. 1998). SNV infection in deer mice is chronic; the virus is maintained in the liver, lungs, kidney, and spleen for the life of the deer mouse (Netski et al. 1999). Although this infection is not fatal (Netski 
et al. 1999), infected hosts experience an increase in concentrations of proinflamatory cytokines (Herbst et al. 2001), and in response to this chronic infection, deer mice continue to produce SNV-specific antibodies throughout their lifetime (Netski et al. 1999). Thus, SNV presents a constant immune challenge. Over time, persistent activation of the immune system may reduce the ability of deer mice to respond adequately to other types of infections (Klasing and Barnes 1988; Råberg et al. 1998; Borkow et al. 2000).

To measure general immunocompetence of deer mice, we used phytohemagglutinin (PHA), a rapidly acting $(<12 \mathrm{~h}) \mathrm{im}$ mune challenge agent. PHA results in profuse cytokine infiltration of local tissue (Martin et al. 2004, 2006) and has been used in numerous ecological studies to assess lymphocyte activity in a variety of animal species (Goto et al. 1978; Williams et al. 1979; Derting and Compton 2003; Martin et al. 2004). Because lymphocytes are effectors of the cell-mediated immune response, PHA has been used to indirectly assess an animal's cell-mediated immunocompetence. The degree of swelling that follows PHA injection is positively correlated with the level of cell-mediated immune response. Animals that are fully immunocompetent produce the greatest amount of swelling, whereas animals that are immunosuppressed produce less swelling (Bize et al. 2005; Greenman et al. 2005). In general, immunocompetence is defined as an individual's ability to develop an immune response to infection or disease (Hecht and Shiel 2003). Thus, in this study, immunocompetence is defined as the ability of the animal to mount an immune response to PHA.

Our primary objective was to test the resource allocation hypothesis in wild deer mice in different reproductive states that had been exposed to SNV, using PHA to gauge cellmediated immunity. We first validated the efficacy of PHA in generating immune responses in laboratory-bred deer mice and then applied this technique to wild populations. We compared differences in immune response between SNV-seropositive and seronegative wild deer mice that were either reproductive or nonreproductive. The resource allocation hypothesis predicts that reproductive animals should be less immunocompetent, as evidenced by smaller immune responses after PHA injection, than nonreproductive animals. Furthermore, because chronic infection is thought to depress the immune system, we predicted that SNV-seropositive deer mice would mount a smaller immune response, as indicated by reduced swelling after PHA injection, than seronegative deer mice. Finally, we predicted that nonreproductive deer mice who were also SNV seronegative would mount the greatest immune response after PHA challenge, whereas deer mice who were both reproductive and SNV seropositive were expected to mount the smallest immune response.

\section{Methods}

\section{Laboratory Validation of PHA Technique}

Adult ( $>3$ mo of age), nonreproductive, laboratory-bred deer mice were obtained from the Peromyscus Genetic Stock Center (Columbia, SC) and were held under standard conditions at the University of Utah for the duration of the laboratory study. Because a range of PHA doses have been used on a variety of species, we first determined the appropriate dose for deer mice. To this end, we randomly assigned individuals to low-dosage or high-dosage PHA treatment groups. Each treatment group contained nine males and nine females. Before injection with PHA, we measured diameters of left and right hind limbs to the nearest $0.01 \mathrm{~mm}$ using a handheld Starrett micrometer (Athol, MA). The low-dosage treatment group was injected in the musculature of the ventral side of the left hind limb with $0.1 \mathrm{~mL}$ of a $0.04 \mathrm{mg} / \mathrm{mL}$ solution of crystalline PHA (Sigma L9017) diluted in phosphate-buffered saline (PBS). The highdosage treatment group was injected with $0.1 \mathrm{~mL}$ of a $0.08 \mathrm{mg} /$ mL PHA solution. As an internal control, the right hind limbs of all deer mice were injected with an identical volume $(0.1$ $\mathrm{mL}$ ) of PBS. Hind limb diameters were measured 3, 6, 12, and $24 \mathrm{~h}$ after injection.

\section{Field-Based Immunocompetence Study}

In May 2004, deer mice were livetrapped (Sherman Traps) at four study sites near the West Tintic Mountains in the Great Basin Desert of central Utah (Juab County). Each site consisted of a web design of 148 traps (Mills et al. 1999) distributed over 3.14 ha. Vegetative communities of each site were dominated by big sagebrush (Artemisia tridentata) and Utah juniper (Juniperus osteosperma).

After capture, deer mice were weighed, sexed, and uniquely marked with numbered ear tags. Deer mice weighing less than $14 \mathrm{~g}$ were eliminated from the study because these animals are considered to be juveniles (Borucki et al. 2000; Calisher et al. 2001). Reproductive condition of individual deer mice was determined by physical examination; females were considered reproductive if they were visibly perforate, pregnant, or lactating, whereas males were considered reproductive if they were visibly scrotal. To determine the SNV infection status of animals, we collected $\sim 0.2 \mathrm{~mL}$ of blood from the retro-orbital sinus of all deer mice. Blood was immediately stored on dry ice and later in a $-80^{\circ} \mathrm{C}$ freezer until being tested for SNV antibodies. After blood collection, diameters of the left and right hind limbs of all deer mice were measured to the nearest $0.01 \mathrm{~mm}$. Left hind limbs of wild deer mice were injected with $0.1 \mathrm{~mL}$ of a 0.08 $\mathrm{mg} / \mathrm{mL}$ PHA solution, whereas their right hind limbs were injected with $0.1 \mathrm{~mL}$ of PBS. After PHA injections, deer mice were held in live traps in a shaded, isolated outdoor area for at least $6 \mathrm{~h}$ before remeasurement of hind limbs. Hind limbs were remeasured between 6 and $7 \mathrm{~h}$ after capture. Once final 
hind limb diameters had been determined, deer mice were released at their locations of capture. In total, deer mice remained in captivity for less than $8 \mathrm{~h}$ and were directly handled for less than $10 \mathrm{~min}$ each. All personnel involved in trapping and handling rodents took precautions for working with animals potentially infected with hantavirus (CDC 1995), and all techniques used in the handling, capturing, and processing of deer mice were approved by the Institutional Animal Care and Use Committee at the University of Utah (05-03011).

\section{Sin Nombre Antibody Detection}

Enzyme-linked immunosorbent assays (ELISAs) were used to screen deer mouse blood for immunoglobulin G (IgG) antibodies to SNV. Because deer mice produce virus-specific IgG antibodies continuously after infection with SNV, presence of antibodies is a reliable indicator of SNV infection (Borucki et al. 2000; Botten et al. 2003; Safronetz et al. 2006). In this process, wells of polyvinyl chloride microtiter plates (Dynatech) were coated overnight at $4^{\circ} \mathrm{C}$ with recombinant nucleocapsid antigen diluted $1: 2,000$ in PBS. A nonhantavirus recombinant antigen was used as a negative control. After incubation, unbound antigen was removed from wells by washing three times with wash buffer. Deer mouse serums were heat inactivated by placing in a $55^{\circ} \mathrm{C}$ water bath for $30 \mathrm{~min}$. Heat-inactivated serums were diluted $1: 100$ in serum-dilution buffer containing powdered nonfat milk, Tween 20 , and $10 \times$ PBS in a $1: 1: 20$ ratio. The diluted sera solution was added to the antigen-coated wells, and plates were then incubated at $37^{\circ} \mathrm{C}$ for $60 \mathrm{~min}$. Plates were then washed three times with wash buffer $(1: 20$ Tween and $10 \times \mathrm{PBS}$ ) and incubated at $37^{\circ} \mathrm{C}$ for $30 \mathrm{~min}$ with $100 \mu \mathrm{L}$ of ABTS Microwell Peroxidase Substrate solution (Kirkegaard and Perry Laboratories; Borucki et al. 2000). Absorbance (405 $\mathrm{nm}$ ) was recorded with a Versa Max Tunable Microplate Reader (VWR International), and values $>3$ standard deviations from those of the negative control wells contained on each plate were considered positive for anti-SNV antibodies (Borucki et al. 2000). All steps in the heat activation of sera were performed in a laminar flow hood in a BSL-3 facility at the University of Nevada. The presence of SNV-specific antibodies in adults is strongly correlated with active SNV infections; ELISA results for SNV antibodies have a concordance of about $70 \%$ with the presence of viral RNA in blood as determined by reverse-transcriptase polymerase chain reaction (Rowe et al. 1995; Otteson et al. 1996). The remaining 30\% of seropositive animals includes adults with antibody titers too low for detection and/or uninfected juveniles with maternal antibodies from SNVpositive dams.

\section{Statistical Analyses}

To evaluate the possibility that left and right hind limbs of deer mice were naturally different in size, we used paired $t$-tests to compare differences in diameter between left and right hind limbs before initial injections. We used repeated-measures ANOVA to determine whether injection with PBS alone resulted in hind limb swelling and whether male and female deer mice differed in their response to PBS injection. In this model, hind limb diameter was the dependent, repeatedly measured variable and sex was the independent variable.

For the laboratory validation study, we used repeated-measures ANOVA to determine whether PHA-induced swelling differed between the high and low dosages of PHA or between male and female deer mice across time intervals. In this model, hind limb diameter was the dependent, repeatedly measured variable, whereas sex, dosage, and interaction terms were the independent variables. Differences between individual time intervals were determined using least squares means comparisons, with Bonferroni adjustments for multiple comparisons. Results of these post hoc tests were used to determine the most appropriate time interval to measure postinjection swelling in deer mice held under field conditions.

To determine whether wild deer mice respond differently to PHA injection than laboratory-bred deer mice, we used oneway ANOVA for both males and females. PHA-induced swelling was the dependent variable, and the habitat (laboratory or field) was the independent variable.

To determine differences in the proportion of SNV-seropositive male and female deer mice, $\chi^{2}$ analysis was used. To determine whether PHA-induced swelling differed between males and females, a one-way ANOVA was used, with sex as the independent categorical factor. Then, for both males and females, independent two-way ANOVAs were used to determine whether PHA-induced swelling differed with reproductive condition or SNV infection status. Differences between individual categories were measured using least squares means comparisons with Tukey-Kramer adjustments for multiple comparisons. Differences in all statistical analyses were considered to be statistically significant if $\alpha \leq 0.05$.

\section{Results}

\section{Laboratory Validation of PHA Technique}

We found no differences between the left and right hind limb diameters of captive deer mice before injection (right $=3.05$ mm vs. left $=3.13 \mathrm{~mm} ; t_{35}=1.46, P=0.17$ ). Injection with $\mathrm{PBS}$ as an intra-animal control did not elicit a swelling response in captive deer mice; their hind limb diameters did not change over consecutive time intervals $\left(F_{4,136}=0.32, P=0.87\right)$. Likewise, there was no difference in response to PBS injection between male and female deer mice $\left(F_{1,34}=0.05, P=0.90\right)$. Therefore, we estimated PHA swelling response by subtracting the diameter of the treatment limb before injection with PHA from the treatment limb diameter after injection.

Deer mice produced considerable swelling in response to PHA injection (within subjects: $F_{3,96}=360.95, P<0.01$ ). There 
was no significant difference in the amount of hind limb swelling between the low- and high-dose injections of PHA $\left(F_{1,32}=0.69, P=0.41\right)$ across time intervals. Female deer mice produced a more than $28 \%$ greater swelling response than males (females $=0.23 \mathrm{~mm}$ vs. males $=0.18 \mathrm{~mm} ; F_{1,32}=12.04, P<$ $0.01)$, and there were no sex by dose interactions $\left(F_{1,32}=\right.$ $0.40, P=0.53)$, indicating that male and female deer mice had similar responses to PHA concentrations. Differences in PHAinduced swelling between male and female deer mice prompted us to consider sex as a factor in the remainder of our statistical analyses for the laboratory validation study.

The magnitude of swelling differed across time intervals in both male $\left(F_{3,68}=12.5, P<0.01\right)$ and female $\left(F_{3,68}=19.9\right.$, $P<0.01$; Fig. 1) deer mice. Hind limb diameters peaked $6 \mathrm{~h}$ after PHA injection and at that time were significantly greater than at the time of injection (male: $t_{17}=29.07, P<0.01$; female: $\left.t_{17}=36.20, P<0.01\right)$.

\section{Field-Based Immunocompetence Study}

Over 6 d (888 trap nights), we captured 112 unique adult deer mice- 51 females and 61 males. There was no difference between the left and right hind limb diameters of wild deer mice (left $=2.98 \mathrm{~mm}$ vs. right $\left.=2.96 \mathrm{~mm} ; t_{111}=0.64, P=0.53\right)$. Injection with PBS as an intra-animal control did not elicit a marked swelling response in wild deer mice; their hind limb diameters were unchanged from the initial to the final measurement $\left(t_{111}=0.39, P=0.70\right)$. Of 112 deer mice captured, IgG antibodies against SNV were detected in 36 individuals, indicating that overall SNV seroprevalence was about 32\%. SNV seroprevalence was higher among male deer mice than among females $\left(\right.$ males $=37 \%$ vs. females $=25 \% ; \chi^{2}=60.02, P<$ 0.01 ). The SNV prevalence we observed is similar to that reported in other deer mouse populations in the same geographic region (Otteson et al. 1996; Douglass et al. 2001; Kuenzi et al. 2001; Mackelprang et al. 2001). Nearly $71 \%$ of deer mice sampled were reproductive, including 36 females (71\%) and 43 males $(70 \%)$.

As in the laboratory trials, there were differences in swelling between male and female deer after following injection with PHA. Females produced a $12 \%$ greater swelling response than males $\left(\right.$ females $=0.28 \mathrm{~mm}$, males $=0.25 \mathrm{~mm} ; F_{1,108}=4.29$, $P=0.04$ ). Because of these sex-based differences, we considered male and female deer mice independently in the remainder of our statistical analyses.

The PHA swelling response of female deer mice differed with both infection status $\left(F_{1,46}=11.99, P<0.01\right)$ and reproductive condition $\left(F_{1,46}=8.20, P<0.01\right)$. There was also a significant infection status by reproductive condition interaction $\left(F_{1,46}=23.56, P<0.01\right)$. Nonreproductive, seropositive females experienced the least amount of swelling, whereas females in all other categories (reproductive, seropositive; nonreproductive, seronegative; reproductive, seronegative) had significantly

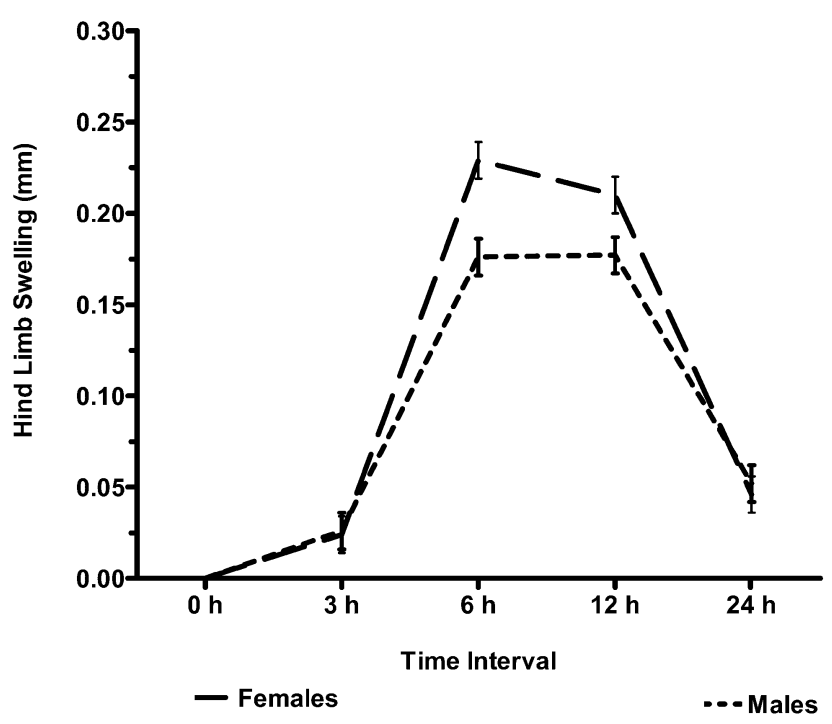

Figure 1. Change in hind limb diameter of laboratory-bred male and female deer mice (Peromyscus maniculatus) in response to injection with phytohemagglutinin (PHA). Hind limb diameters were measured with a handheld micrometer before PHA injection and then $3,6,12$, and $24 \mathrm{~h}$ postinjection. Hind limb diameter peaked $6 \mathrm{~h}$ postinjection and at that time was significantly different from values at the time of injection.

greater $(P<0.05)$ and similar amounts of swelling $(P>0.05$; Fig. 2). The PHA swelling response of male deer mice differed with both SNV infection status $\left(F_{1,56}=306.77, P<0.01\right)$ and reproductive condition $\left(F_{1,56}=10.08, P<0.01\right)$, but there was no significant infection status by reproductive condition interaction $\left(F_{1,56}=0.09, P=0.77\right)$. Seronegative males elicited greater swelling than seropositive males regardless of reproduction status $(P<0.01$; Fig. 3$)$.

\section{Comparison of Laboratory and Wild Deer Mice}

Comparisons of swelling between captive and wild deer mice indicated that deer mice in the field elicited greater swelling than laboratory deer mice. Wild females had $22 \%$ greater swelling than laboratory-bred females $(0.28 \pm 0.01$ vs. $0.23 \pm 0.01$ $\left.\mathrm{mm} ; F_{1,66}=9.56, P<0.01\right)$, whereas the swelling of wild male deer mice was 39\% greater than that of laboratory-bred male deer mice $\left(0.25 \pm 0.01\right.$ vs. $0.18 \pm 0.01 \mathrm{~mm} ; F_{1,76}=15.95, P<$ $0.01)$.

\section{Discussion}

Our primary objective was to test the resource allocation hypothesis in wild deer mice in different reproductive states with natural exposure to SNV. We predicted that reproductive deer mice or those infected with SNV would mount a smaller immune response than nonreproductive or uninfected individuals, as gauged by swelling response after PHA injection. Below, we 


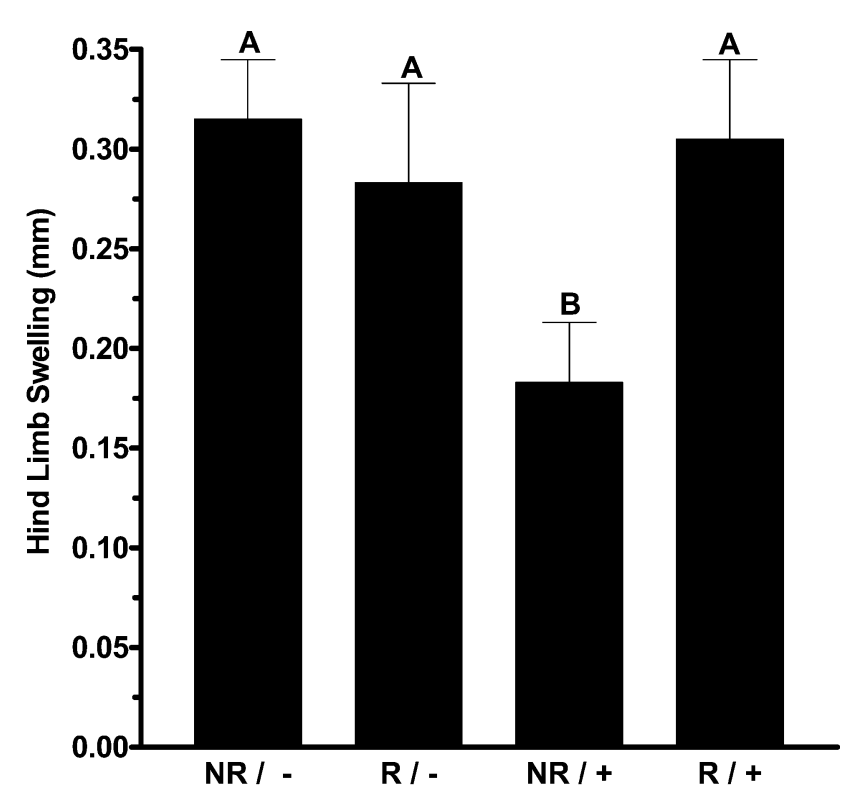

Figure 2. Mean change in hind limb diameter $( \pm$ SE) of wild female deer mice (Peromyscus maniculatus) $6 \mathrm{~h}$ after injection with phytohemagglutinin). Deer mice were grouped into four categories based on their reproductive condition and Sin Nombre virus infection status: nonreproductive/seronegative $(\mathrm{NR} /-)$; reproductive/seronegative $(\mathrm{R} /-)$; nonreproductive/seropositive $(\mathrm{NR} /+)$; reproductive/seropositive $(\mathrm{R} /+)$. Means labeled with different letters are statistically significant $(\alpha \leq 0.05)$. Sample sizes for each group were as follows: $\mathrm{NR} /-=11 ; \mathrm{R} /-=28 ; \mathrm{NR} /+=4 ; \mathrm{R} /+=8$.

discuss the efficacy of PHA in generating immune responses in deer mice, the patterns of immunocompetence that we observed in wild populations, and the implications of these findings in the context of the resource allocation hypothesis.

\section{Efficacy of PHA in Deer Mice}

Our results demonstrate that PHA is effective in generating a measurable swelling response in deer mice, a species in which this technique has not been previously used. We found that maximal swelling occurred in a relatively short period of time $(6-12 \mathrm{~h})$, which is in contrast to several published studies in birds that typically measure swelling $24 \mathrm{~h}$ after PHA injection (Smits et al. 1999; Granbom et al. 2004; Haussmann et al. 2005). That the immune response generated by PHA injection occurs within a short time frame underscores the utility of this technique and makes the use of PHA particularly attractive for studies where maintaining captive animals infected with biohazardous agents such as SNV is not possible.

\section{Sex-Based Differences in Immunocompetence}

The results of our study are consistent with the hypothesis that males have lower immunocompetence and therefore may be more susceptible to infection with SNV. Male deer mice were generally less immunocompetent than females; they experienced less swelling in response to PHA challenge in both laboratory and field settings. Furthermore, SNV seroprevalence of males was nearly 1.5 times greater than that of females. In general, disease prevalence is often higher in males than in females, including parasitic, bacterial, and viral infections (Grossman 1985; Møller et al. 1998; Moreno et al. 2001). A higher incidence of infection among males has been observed in several strains of Hantavirus, including Sin Nombre, El Moro Canyon, Puumala, and Seoul viruses (Weigler et al. 1996; Mills et al. 1997; Bernstein et al. 1999). Laboratory studies report that SNV is shed and transmitted less efficiently than other hantaviruses, which suggests that infection with SNV may depend on reduced immunocompetence of the host (Dohmae et al. 1993; Botten et al. 2002). Our results support this prediction, indicating that in the natural environment, reduced immunocompetence of male deer mice may confer greater susceptibility to SNV infection.

\section{Differential Resource Allocation}

In general, our results do not support the idea that reproductive activity suppresses immunocompetence of deer mice but rather indicate that a chronic SNV infection can reduce the ability of the immune system to respond to additional challenges. Our results show that there are no appreciable differences in PHAinduced swelling between reproductive and nonreproductive

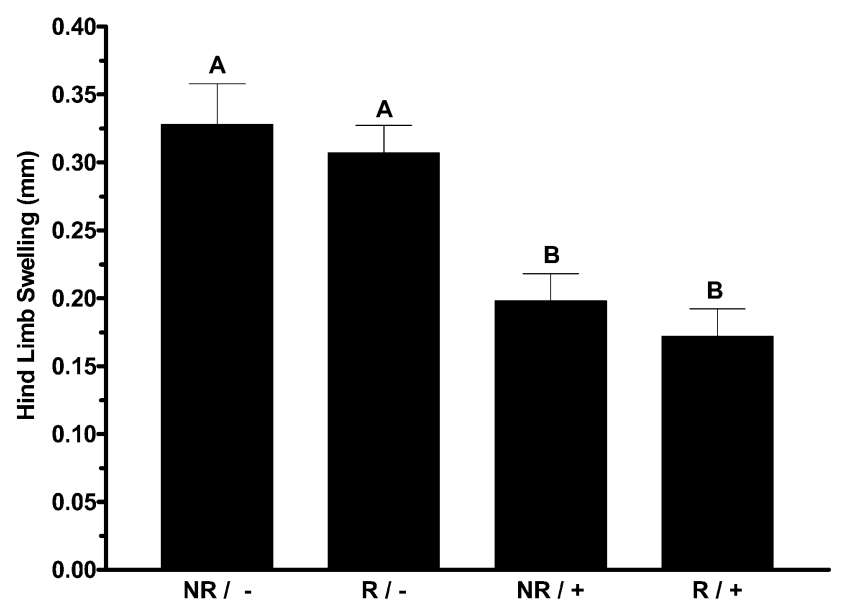

Figure 3. Mean change in hind limb diameter $( \pm S E)$ of wild male deer mice (Peromyscus maniculatus) $6 \mathrm{~h}$ after injection with phytohemagglutinin. Deer mice were grouped into four categories based on their reproductive condition and Sin Nombre virus infection status: nonreproductive/seronegative $(\mathrm{NR} /-)$; reproductive/seronegative $(\mathrm{R} /-)$; nonreproductive/seropositive $(\mathrm{NR} /+)$; reproductive/seropositive $(\mathrm{R} /+)$. Means labeled with different letters are statistically significant $(\alpha \leq 0.05)$. Sample sizes for each group were as follows: $\mathrm{NR} /-=13 ; \mathrm{R} /-=25 ; \mathrm{NR} /+=5 ; \mathrm{R} /+=18$. 
males with the same infection status, and we found similar patterns for SNV-seronegative females. Although laboratorybased studies have shown that hantaviruses do have an immediate impact on deer mice survival (Hjelle and Yates 2001; Yee et al. 2003), our results in wild deer mice counter this interpretation: reduced immunocompetence associated with SNV infection could render hosts more susceptible to other pathogenic infections, which may directly limit their longevity or fertility. It is noteworthy that the incidence of new hantaviral infections among hosts varies across seasons and is generally highest during periods coinciding with peak reproductive activity (Klein et al. 2002). Higher incidences of SNV infection may result from behavioral changes associated with reproduction, such as increased contact and aggression among conspecifics (Childs et al. 1987; Glass et al. 1998; Hinson et al. 2004; Klein et al. 2004), rather than from differences in immunocompetence.

Sex-based differences in the PHA-induced immune response of deer mice indicate that SNV modulates the immune system of females differently from that of males, particularly during reproduction. Reproductive female deer mice that were also SNV seropositive appeared to have elevated cell-mediated immunocompetence; they experienced significantly greater swelling in response to PHA injection compared to females that were SNV seropositive but nonreproductive. It is important to emphasize that PHA measures only one facet of an animal's immune system function (i.e., cell-mediated immunity) and also that energetic costs of reproduction could differ between females in different reproductive states (e.g., perforate, pregnant, lactating), which we did not identify. However, our results are in stark contrast to our original prediction that reproductive activity leads to a reduction in general immunity and suggest that interpretation of the resource allocation hypothesis may not be as straightforward as originally expected.

In its most basic interpretation, the resource allocation hypothesis predicts that animals will shift energetic resources to support functions that promote reproductive success; however, the mechanisms that males and females use to promote reproductive success are inherently different. For example, male deer mice have very little parental investment and thus enhance reproductive success by increasing mating frequency (Armitage 1986, 1998). As such, after conception, immunocompetence of the father has little or no influence on the fitness of their offspring. In contrast, female deer mice have much higher parental investment because they must care for offspring from the time of conception until weaning. It is arguable that the allocation of resources to immune function is of paramount importance for reproductive females because their increased immunocompetence from the time of conception until weaning directly benefits the fitness of their offspring. Pregnant and lactating mothers transfer antigen-specific antibodies both transplacentally (Simister and Story 1997) and through milk (Russel et al. 1999; Wilson and Butcher 2004), which protects offspring from infection during the critical time between birth and maturation of the juvenile immune system. Increased immune function also benefits reproductive females during parturition because tissue damage incurred during the birthing process increases risk for contracting opportunistic infections that may interfere with a mother's ability to care for offspring. To counter the natural reduction in immunocompetence that accompanies SNV infection, seropositive females may increase immune function during pregnancy to reduce their susceptibility to such opportunistic infections.

By definition, the resource allocation hypothesis presumes that resources are limited; however, this may be difficult to test under field conditions because of inherent difficulties in measuring resource availability and expenditures. Despite this limitation, results of our study offer a rare insight into the immune system function of wild animals and represent the first empirical test of the resource allocation hypothesis in an endemic disease system. Our findings further the understanding of how SNV is regulated in the natural host system and the mechanisms that influence seasonal variations in the prevalence of zoonotic disease.

\section{Acknowledgments}

Research support provided by an National Institutes of Health (NIH) Training Grant to E.M.L. (AI055434-01A1). Support was also provided by a National Science Foundation-NIH grant (EF 0326999) to M.D.D. and a University of Utah seed grant to M.D.D. We thank L. Kelly, C. Votaw, B. Wood, and numerous undergraduate students for assistance. The comments of three anonymous reviewers were greatly appreciated.

\section{Literature Cited}

Armitage K. 1986. Marmot polygyny revisited: determinants of male and female reproductive strategies. Pp. 303-331 in D.S. Rubenstein and R.W. Wrangham, eds. Ecological Aspects of Social Evolution. Princeton University Press, Princeton, NJ. . 1998. Reproductive strategies of yellow-bellied marmots: energy conservation and differences between the sexes. J Mammal 79:385-393.

Bernstein A., N. Apekina, T. Mikhailova, Y. Myaskikov, L. Khyap, Y. Korotkovm, and I. Gevrilovskaya. 1999. Dynamics of Puumala hantavirus infection in naturally occurring bank voles (Cleithrionomys glareolus). Arch Virol 144:2415-2428.

Bize P., A. Roulin, J.L. Tella, and H. Richner. 2005. Femalebiased mortality in experimentally parasitized Alpine swift Alpus melba nestlings. Funct Ecol 19:405-413.

Borkow G., Q.B. Leng, Z. Weisman, M. Stein, N. Galai, A. Kalinkovitch, and Z. Bentwich. 2000. Chronic immune activation associated with intestinal helminth infections results 
in impaired signal transduction and anergy. J Clin Investig 106:1053-1060.

Borucki M.K., J.D. Boone, J.E. Rowe, M.C. Bohlman, E.A. Kuhn, R. DeBacca, and S.C. St. Jeor. 2000. Role of maternal antibody in natural infection of Peromyscus maniculatus with Sin Nombre virus. J Virol 74:2426-2429.

Botten J., K. Mirowsky, D. Kusewitt, C. Ye, K. Gottlieb, J. Prescott, and B. Hjelle. 2003. Persistent Sin Nombre virus infection in the deer mouse (Peromyscus maniculatus) model: sites of replication and strand-specific expression. J Virol 77: 1540-1550.

Botten J., K. Mirowsky, C. Ye, K. Gottlieb, M. Saavedra, L. Ponce, and B. Hjelle. 2002. Shedding and intercage transmission of Sin Nombre hantavirus in the deer mouse (Peromyscus maniculatus) model. J Virol 76:7587-7594.

Calisher C.H., J.N. Mills, W.P. Sweeney, J.R. Choate, D.E. Sharp, K.M. Cannestorp, and B.J. Beaty. 2001. Do unusual sitespecific population dynamics of rodent reservoirs provide clues to the natural history of hantaviruses? J Wildl Dis 37: 280-288.

CDC. 1995. Methods for Trapping and Sampling Small Mammals for Virologic Testing. Centers for Disease Control and Prevention, Atlanta.

Childs J., G. Korch, G. Glass, J. LeDuc, and K. Shaw. 1987. Epizootiology of hantavirus infections in Baltimore: isolation of virus from Norway rats and characteristics of infected rat populations. Am J Epidemiol 126:55-68.

Dearing M.D., A.M. Mangione, W.H. Karasov, S. Morzunov, E. Otteson, and S. St. Jeor. 1998. Prevalence of hantavirus in four species of Neotoma from Arizona and Utah. J Mammal 79:1254-1259.

Derting T. and S. Compton. 2003. Immune response, not immune maintenance, is energetically costly in white-footed mice (Peromyscus leucopus). Physiol Biochem Zool 76:744752.

Dohmae K., U. Koshimizu, and Y. Nishimune. 1993. In utero and mammary transfer of hantavirus antibody from dams to infant rats. Lab Anim Sci 43:557-561.

Douglass R.J., T. Wilson, W.J. Semmens, S.N. Zanto, C.W. Bond, R.C. Van Horne, and J.N. Mills. 2001. Longitudinal studies of Sin Nombre virus in deer mouse-dominated ecosystems in Montana. Am J Trop Med Hyg 65:33-41.

Festa-Bianchet M. 1989. Individual differences, parasites, and the costs of reproduction for bighorn ewes (Ovis canadensis). J Anim Ecol 58:785-795.

Glass G., J. Childs, G. Korch, and J. LeDuc. 1998. Association of intraspecific wounding with hantaviral infection in wild rats (Rattus norvegicus). Epidemiol Infect 101:459-472.

Goto N., H. Kodama, K. Okada, and Y. Fujimoto. 1978. Suppression of phytohemagglutinin skin response in thymectomized chickens. Poult Sci 57:246-250.

Granbom M., L. Råberg, and H.G. Smith. 2004. The spatial and temporal repeatability of PHA-responses. Behav Ecol 16: 497-498.

Greenman C., L.B. Martin, and M. Hau. 2005. Reproductive state, but not testosterone, reduces immune function in male house sparrows (Passer domesticus). Physiol Biochem Zool 78:60-68.

Grossman C. 1985. Interactions between gonadal steroids and the immune system. Science 227:257-261.

Gustafsson L., D. Nording, M. Anderson, B. Sheldon, and A. Qvanstrom. 1994. Infectious diseases, reproductive effort and the cost of reproduction in birds. Philos Trans R Soc B 346: 323-331.

Haussmann M.F., D.W. Winkle, C.E. Huntington, D. Vleck, C.E. Sanneman, D. Hanley, and C.M. Vleck. 2005. Cellmediated immunosenescence in birds. Oecologia 145:270 275.

Hecht F. and W.C. Shiel. 2003. Webster's New World Medical Dictionary. 2nd ed. Wiley, New York.

Herbst M., J. Prescott, A. Palmer, and T. Schountz. 2001. Sequence and expression analysis of deermouse interferon $\gamma$, interleukin 10, tumor necrosis factor $\alpha$, and lymphotoxin $\alpha$. Cytokine 17:203-213.

Hinson E.R., S.M. Shone, M.C. Zink, G.E. Glass, and S.L. Klein. 2004. Wounding: the primary mode of Seoul virus transmission among male Norway rats. Am J Trop Med Hyg 70: 310-317.

Hjelle B. and T. Yates. 2001. The hantaviruses. Pp. 77-90 in C.S. Smaljohn and S.T. Nichol, eds. Modeling Hantavirus Maintenance and Transmission in Rodent Communities. Springer, Berlin.

Klasing K.C. and D.M. Barnes. 1988. Decreased amino acid requirements of growing chicks due to immunologic stress. J Nutr 118:1158-1164.

Klein S., B. Bird, R. Nelson, and G. Glass. 2002. Environmental and physiological factors associated with Seoul virus infection among urban populations of Norway rats. J Mammal 83:478-488.

Klein S.L., M.C. Zink, and G.E. Glass. 2004. Seoul virus increases aggressive behaviour in male Norway rats. Anim Behav 67:421-429.

Kuenzi A.J., R.J. Douglass, D. White, C.W. Bond, and J.N. Mills. 2001. Antibody to Sin Nombre virus in rodents associated with peridomestic habitats in west central Montana. Am J Trop Med Hyg 64:137-146.

Mackelprang R., M.D. Dearing, and S. St. Jeor. 2001. High prevalence of Sin Nombre virus in rodent populations, central Utah: a consequence of human disturbance? Emerg Infect Dis 7:481.

Martin L.B., P. Han, J. Lewittes, J.R. Kuhlman, K.C. Klasing, and M. Wikelski. 2006. Phytohemagglutinin-induced skin swelling in birds: histological support for a classic immunoecological technique. Funct Ecol 20:290-299.

Martin L.B., M. Pless, J. Svoboda, and M. Wikelski. 2004. Im- 
mune activity in temperate and tropical house sparrows: a common garden experiment. Ecology 85:2323-2331.

Martin L.B., A. Scheuerlein, and M. Wikelski. 2003. Immune activity elevates energy expenditure of house sparrows: a link between direct and indirect costs. Proc R Soc B 270:153158.

Mills J.N., T. Ksiazek, B. Ellis, P. Rollin, T. Nicho, T. Yates, W. Gannon, et al. 1997. Patterns of association with host and habitat: antibody reactive with Sin Nombre virus in small mammals in the major biotic communities of the southwestern United States. Am J Trop Med Hyg 56:273-284.

Mills J.N., T.G. Ksiazek, C.J. Peters, and J.E. Childs. 1999. Longterm studies of hantavirus reservoir populations in the southwestern United States: a synthesis. Emerg Infect Dis 5:135142.

Møller A.P., G. Sorci, and J. Errizoe. 1998. Sexual dimorphism in immune defense. Am Nat 152:605-619.

Moreno J., J. Potti, P. Yorio, and P.G. Borboroglu. 2001. Sex differences in cell-mediated immunity in the Magellanic penguin Spheniscus magellanicus. Ann Zool Fenn 38:111-116.

Nelson R., G. Demas, S. Klein, and L. Kriegsfeld. 2002. Seasonal Patterns of Stress, Immune Function, and Disease. Cambridge University Press, New York.

Netski D., B.H. Trahn, and S.C. St. Jeor. 1999. Sin Nombre virus pathogenesis in Peromyscus maniculatus. J Virol 73:585591.

Otteson E., J. Riolo, J. Rowe, S. Nichol, T. Ksiazek, P. Rollin, and S. St. Jeor. 1996. Occurrence of hantavirus within the rodent population of northeastern California and Nevada. Am J Trop Med Hyg 54:127-133.

Råberg L., M. Grahn, D. Hasselquist, and E. Svensson. 1998. On the adaptive significance of stress-induced immunosuppression. Proc R Soc B 265:1637-1641.

Rowe J.E., S.C. St. Jeor, J. Riolo, E.W. Otteson, M.C. Monroe, W.W. Henderson, T.G. Ksiazek, P.G. Rollin, and S.T. Nichol. 1995. Coexistence of several novel hantaviruses in rodents indigenous to North America. Virology 213:122-130.
Russel M.W., M. Kilian, and M.E. Lamm. 1999. Biological activities of IgA. Pp. 225-240 in P.L. Ogra, J. Mestecky, M.E. Lamm, W. Strober, J. Bienenstock, and J.R. McGhee, eds. Mucosal Immunology. Academic Press, San Diego, CA.

Safronetz D., R. Lindsay, B. Hjelle, R.A. Medina, K. MirowskyGarcia, and M.A. Drebot. 2006. Use of IgG avidity to indirectly monitor epizootic transmission of Sin Nombre virus in deer mice (Peromyscus maniculatus). Am J Trop Med Hyg 75:1135-1139.

Sheldon B.C. and S. Verhulst. 1996. Ecological immunology: costly parasite defences and trade-offs in evolutionary ecology. Trends Ecol Evol 11:317-322.

Simister N.E. and C.M. Story. 1997. Human placental Fc receptors and the transmission of antibodies from mother to fetus. J Reprod Immunol 37:1-23.

Sinclair J. and R. Lochmiller. 2000. The winter immunoenhancement hypothesis: associations among immunity, density, and survival in prairie vole (Microtus ochrogaster) populations. Can J Zool 78:254-264.

Smits J., G. Bortolotti, and J. Tella. 1999. Simplifying the phytohemagglutinin skin-testing technique in studies of avian immunocompetence. Funct Ecol 13:567-572.

Weigler B.J., T.G. Ksiazek, J.G. Vandenbergh, M. Levin, and W.T. Sullivan. 1996. Serological evidence for zoonotic hantaviruses in North Carolina rodents. J Wildl Dis 32:354-357.

Williams E.A., B.M. Gebhardt, B. Morton, and P.M. Newberne. 1979. Effects of early marginal methionone-choline deprivation on the development of the immune system in the rat. Am J Clin Nutr 32:1214-1233.

Wilson E. and E.C. Butcher. 2004. CCL28 controls immunoglobulin (Ig): a plasma cell accumulation in the lactating mammary gland and IgA antibody transfer to neonate. J Exp Med 200:805-809.

Yee J., I.A. Wortman, R.A. Nofchlssey, D. Goade, S.G. Bennett, J.P. Webb, W. Irwin, and B. Hjelle. 2003. Rapid and simple method for screening wild rodents for antibodies to Sin Nombre hantavirus. J Wildl Dis 39:271-277. 